\title{
THE FRAGILE BOUNDARY BETWEEN "EDUCATION" AND "EDUCATIONALISATION": SOME PERSONAL REFLECTIONS ON THE OFTEN EXAGGERATED EDUCATIONAL ASPIRATIONS OF MUSEUMS
}

\author{
La frágil frontera entre "educación» y «educacionalización»: \\ algunas reflexiones personales sobre las aspiraciones, \\ a menudo exageradas, de los museos
}

\section{Marc Depaepe ${ }^{\alpha}$}

Reception date: 06/11/2021 • Acceptation date: 03/12/2021

Abstract. Although the origins of school museums and museums of children and childhood do not coincide directly, they nevertheless have moved into the same direction during the past decades. Especially because children are an important part of the visitors, a lot is invested by these museums in educational support and activities. Pedagogical arguments form the backbone of their mission statements. A bit against the tide of this trend, I want to pay attention here to the often exaggerated educational aspirations. To my mind the boundary between "education" and "educationalisation" is a fragile one and can be easily exceeded if the cultural-historical context of the museum content is ignored too much. Educating young people does not necessarily mean taking them by the hand and leading them through well-developed work packages, but is related to the more complex process of Bildung - the formation of a person, which usually starts, in view of attitudes and behaviour, by reflection about self-identity as well as societal values and norms. In my opinion the encounter with well-chosen artefacts of former pedagogical mentalities and realities in museums of education, children and childhood, can be helpful in this respect. Therefore, my plea for more culture-historical contemplation and less educational strategy in representing education, children and childhood is not to be understood as phasing

\footnotetext{
${ }^{\alpha}$ Emeritus Professor at the KU Leuven, Campus Kulak (Etienne Sabbelaan, 53 B- 8500 Kortrijk, Belgium) \& Leading Researcher at the University of Latvia (Riga, Latvia). marc.depaepe@kuleuven.be

How to cite this article: Depaepe, Marc. "The fragile boundary between 'education' and 'educationalisation': some personal reflections on the often exaggerated educational aspirations of museums". Historia y Memoria de la Educación 15 (2022): 389-419
} 
out efforts in this sector. On the contrary, the shift of emphasis from the neoliberal focus on efficiency, management, and social relevance (also in terms of a possible instrumentalization) of educational history towards more scientific, cultural-historical underpinning will need continuous support.

Keywords: Educational historiography; Childhood history; Representation in museums; Latvia; Belgium.

Resumen. Aunque los orígenes de los museos escolares y de los museos de la infancia y la niñez no coinciden directamente, sin embargo, se han movido en la misma dirección durante las últimas décadas. Especialmente porque los niños son una parte importante de los visitantes, estos museos invierten mucho en apoyo y actividades educativas. Los argumentos pedagógicos constituyen la columna vertebral de sus declaraciones de su misión. Un poco a contracorriente de esta tendencia, quiero prestar atención aquí a las aspiraciones educativas, a menudo exageradas. En mi opinión, la frontera entre "educación» $y$ "pedagogización» es frágil y puede sobrepasarse fácilmente si se ignora en exceso el contexto cultural-histórico del contenido del museo. Educar a los jóvenes no significa necesariamente llevarlos de la mano y conducirlos a través de paquetes de trabajo bien desarrollados, sino que está relacionado con el proceso más complejo de Bildung - la formación de una persona, que suele comenzar, en vista de las actitudes y el comportamiento, por la reflexión sobre la identidad propia, así como sobre los valores y normas sociales. En mi opinión, el encuentro con artefactos bien elegidos de antiguas mentalidades y realidades pedagógicas en los museos de la educación, los niños y la infancia puede ser útil a este respecto. Por lo tanto, mi petición de una mayor contemplación histórico-cultural y una menor estrategia educativa en la representación de la educación, la infancia y los niños no debe entenderse como una eliminación progresiva de los esfuerzos en este sector. Por el contrario, el cambio de énfasis desde el enfoque neoliberal en la eficiencia, la gestión y la relevancia social (también en términos de una posible instrumentalización) de la historia de la educación hacia un apuntalamiento más científico e histórico-cultural necesitará un apoyo continuo.

Palabras clave: Historiografía educativa; Historia de la infancia; Representación en museos; Letonia; Bélgica. 
"This story hits more marks than you suppose. All critics, pedants, men of endless prose,

No matter what the task, Their precious tongues must teach; Their help in need you ask, You first must hear them preach". ${ }^{1}$

(J. de La Fontaine, 1668)

\section{AN UNEXPECTED QUESTION THAT PROMPTED A FEW PERSONAL REFLECTIONS}

In 2020, Iveta Kestere succeeded in winning a research project at the University of Latvia looking into the representation of childhood in her country's museums. ${ }^{2}$ Given the fact that I - since becoming an emeritus at Leuven - have had links with that very same university as a leading researcher, my colleague asked me right from the start whether I wanted to take part. Both out of gratitude and out of curiosity, I immediately accepted her offer. That said, I don't actually have a huge amount of expertise in this matter, even though I was involved as a content consultant in the design of the now-defunct Education Museum in Ypres between 1991 and 2017. However, that doesn't exactly make me a museum educator or a specialist in museology, and I'm afraid I can't claim to be a historical researcher of childhood either. One thing I can rightly lay claim to are the various publications on the history of education I've worked on over the course of my career, including in connection with the activities of education museums. ${ }^{3}$ Whether that suffices to help develop the

\footnotetext{
${ }^{1}$ Quotes from "The Boy and the Schoolmaster" (originally 1668), in: The fables of La Fontaine Translated from the French by Elizur Wright [original place and date: Boston, USA, 1841]. A New Edition, with notes by J. W. M. Gibbs, 1882 .

${ }^{2}$ University of Latvia, Research project lzp-2020/2-0282: "Representation of childhood in the museums of Latvia, integrated in the e-learning environment of higher education". The present article is also a contribution to this project. The paper was originally presented at the international conference "stories on childhood: history, memory and research", 22-23 October 2021, Riga, Latvia, which was also part of the project.

${ }^{3}$ About my work, also in the context of museums, see, e.g., interviews in history of education journals: S. Polenghi \& G. Bandini, "Interview with Marc Depaepe", Espacio, Tiempo y Educación 3, n. 1 (2016): 445-453; J.M. Hernández Díaz, "Conversación con Marc Depaepe. Historiador de la educación, Universidad Católica de Lovaina (Bélgica)”, Historia de la educación 39 (2020): 437-459; F. Maas, "Een
} 
theoretical-methodological foundations of the aforementioned research project - something I'm ostensibly expected to do - is a whole different matter altogether. Regardless, it is likely that this project will be able to draw on some of my considerations on the nature and identity of educational historiography that I have shared as part of various publications over the years. ${ }^{4}$

From the late 18th century, the concept of "being a child" slowly but surely morphed into "being a pupil" as a result of the increasing importance of schools as social institutions. ${ }^{5}$ As a consequence, there are clear parallels between the historiography of childhood and that of education. From a research perspective, that latter discipline has extricated itself further and further from the cocoon of educational sciences over the past few decades, even though it remains mostly embedded in that field from an institutional point of view. Instead of continuing to define itself as an auxiliary science or as an element of pedagogy and/or educational science(s), the history of child rearing and education has gradually started to align itself with social and cultural historiography since the 1960s and 1970s. Together with the success of various new-fangled research methods and techniques in the context of the empirical and analytical "evidence based" exploration of human behaviour (of which child rearing and education are increasingly seen as an element), this

bevrijdende, ontmoetende en soms helende dialoog. Marc Depaepe over onderwijsmusea als laboratoria voor historisch-pedagogisch onderzoek", Lessen. Periodiek van het Nationaal Onderwijsmuseum en de Vereniging van Vrienden 15, no. 2 (2020): 4-7.

${ }^{4}$ For a brief synthesis of my work, see my farewell lecture at the University of Leuven, campus Kulak, published as: M. Depaepe, "Why even today educational historiography is not an unnecessary luxury. Focusing on four themes from forty-four years of research", Espacio, Tiempo y Educación 7, no. 1 (2020): 227-246. In the Liber Amicorum five former students dedicated to me, one can find a profound and critical discussion about my work, see, e.g., Thomas S. Popkewitz, "The Study of Education. On Rethinking History with the Help of Marc Depaepe", in Folds of Past, Present and Future: Reconfiguring Contemporary Histories of Education, eds. S. Van Ruyskensvelde, G. Thyssen, F., Herman, A., Van Gorp \& P. Verstraete (Berlin: De Gruyter, 2021), 39-58; L. Fendler, "Critical Powers of Historical Framing", in Folds of Past, Present and Future: Reconfiguring Contemporary Histories of Education, eds. S. Van Ruyskensvelde, G. Thyssen, F., Herman, A., Van Gorp \& P. Verstraete (Berlin: De Gruyter, 2021): 59-80.

${ }_{5}^{5}$ See, among others, U. Herrmann, Historische Bildungsforschung und Sozialgeschichte der Bildung: Programme - Analysen - Ergebnisse (Weinheim: Deutscher Studien Verlag, 1990); H.E. Tenorth, Geschichte der Erziehung. Einführung in die Grundzüge ihrer neuzeitlichen Entwicklung (Weinheim/München: Juventa, 20003); J. Ch. von Bühler, Die gesellschaftliche Konstruktion des Jugendalters. Zur Entstehung der Jugendforschung am Beginn des 20. Jahrhunderts (Weinheim: Deutscher Studien Verlag, 1990). See also: O. Welply, "A crisis in education? an Arendtian perspective on citizenship and belonging in France and England", British journal of sociology of education 40, no. 6 (2019): 759-775. 
has undoubtedly led to a reduction, and in some cases even the disappearance, of the historical approach (mainly in relation to ideas) on the curriculum of educational courses. On top of that, it may also have led to a lessening of its so-called educational relevance to the field. ${ }^{6}$

That said, I believe it remains to be seen to what extent the near-constant hankering for "lessons" from the educational past (which continues to be part and parcel of the literature to this day) isn't simply an illusion arising from the utilitarian legacy of the Enlightenment: a history-of-mentalities continuation of the utilitarian ideology of modernism that we fall back on to support and/or explain countless social issues and political or ideological motives. In any case, it is difficult to view the rise of "historical pedagogy", as our field has traditionally been referred to in several languages, as separate from the emerging professionalisation of education as an occupation. Halfway through the 19th century, in light of the ever more important role played by schools in nation states, we started searching for (authoritative) arguments from the past in order to elevate the professional ethos of educators ${ }^{7}$ - in sharp contrast to the material conditions they effectively worked in, as a side note. For these reasons, I and the other members of our research group(s) (which varied greatly in terms of composition over the years) have on multiple occasions stood up to defend the intrinsic value of studying the history of education, and by extension, argued in favour of a more scientific attitude in the development of education and school museums, without too many pedagogical or didactic ulterior motives. ${ }^{8}$

\footnotetext{
${ }^{6}$ See, for example, G. McCulloch, The Struggle for the History of Education (London/New York: 2011); McCulloch as well as R. Aldrich, Lessons from History of Education. The selected works of Richard Aldrich (London/New York: Routledge, 2006) are more likely to take a less orthodox stance on the intrinsic value of the discipline of the history of education than I do.

${ }^{7}$ France is a good example: see J. Gautherin, Une discipline pour la république. La science de l'éducation en France (1882-1914) (Berne: Peter Lang, 2002).

${ }_{8}$ Most sharply in: M. Depaepe, "The Ten Commandments of Good Practices in History of Education Research", Zeitschrift für Pädagogische Historiographie 16, no. 1 (2010): 31-34. See further also, among others, M. Depaepe, "How should history of education be written? Some reflections about the nature of the discipline from the perspective of the reception of our work", Studies in Philosophy and Education 23, no. 5 (2004): 333-345; M. Depaepe \& F. Simon, "Sources in the Making of Histories of Education: proofs, arguments, and other reasonings from the historian's workplace", in Educational Research: Proofs, Arguments, and Other Reasonings, eds. P. Smeyers \& M. Depaepe (Dordrecht: Springer, 2009), 23-39; M. Depaepe, "Qualities of Irrelevance? History of Education in the Training of Teachers", in Knowledge, Politics and the History of Education, ed. J. E. Larsen (Münster: LIT-Verlag, 2012), 39-53; K. Van Nieuwenhuyse, F. Simon \& M. Depaepe, "The Place of History in Teacher
} 
After all, "school museums" came into being from the middle of the 19 th century onwards as a result of pedagogical concerns, rather than out of an interest in cultural history. In some cases, they consisted of little more than the continuation of a didactic collection at some world fair or other that was intended to show the public at large the latest tools used to educate school-age children. Consequently, school museums first and foremost served as places where "new" material was collected and stored, which was then used to provide regular demonstrations to promote and support the educational reforms and innovations that occurred in the second half of the 19th century in the broader context of the modernisation of society. During the interbellum, these museums were faced with entirely new political and ideological contexts, and they either suffered as a result, or became increasingly politicised following the rise of "new order" ideas. This is exactly what happened in Germany, Italy and Spain, for example. ${ }^{9}$ The aftermath of the First World War

Training and in Education. A Plea for an Educational Future with a History, and Future Teachers with Historical Consciousness", Bildungsgeschichte. International Journal for the Historiography of Education 5, no.1 (2015): 57-69, and, as far as the material educational heritage and education museums are concerned: M. Depaepe \& F. Simon, "Educação, Património Cultural na Bélgica: Investigação consistente espera por iniciativas museológicas", in Educação e Património Cultural: Escolas, Objetos e Prácticas, ed. M. J. Mogarro (Lisboa: Edições Colibri, 2015), 73-92; M. Depaepe \& F. Simon, "It's All About Interpretation: Discourses at Work in Education Museums. The Case of Ypres", in Educational Research: Discourses of Change and Change of Discourse, eds. P. Smeyers \& M. Depaepe ([Cham]: Springer International Publishing Switzerland, 2016), 207-222; M. Depaepe, "Au bas de la liste des priorités? Quelques réflexions personnelles sur le traitement du patrimoine scolaire en Belgique", in Première rencontre francophone des musées de l'école. Actes Rouen 2016 (Rouen: Le Musée national de l'éducation [Munané], 2018), 65-75; M. Depaepe, "Über den Bildungswert von Schulmuseen", in Bildungsmedien im wissenschaftlichen Diskurs, Hrsg. J. Benecke, A. Richter, H. Schulz-Gade, D. Balcke, M. Schmid (Bad Heilbrunn: Kilinkhardt, 2021), in press ; M. Depaepe, "Like a voice in the wilderness? Striving for a responsible handling of the educational heritage", in Exhibiting the Past: Public Histories of Education, eds. F. Herman, S. Braster \& M. del Mar del Pozo Andrés (Berlin: De Gruyter, 2022), in press.

9 Th. Heese, "Schulmuseen en Allemagne: histoire et situation actuelle des musées de l'école allemands", in Première rencontre francophone des musées de l'école. Actes Rouen 2016 (Rouen: Le Musée national de l'éducation [Munané], 2018), 51-63; A. Ascenzi, M. Brunelli \& J. Meda, "Représentation du passé scolaire dans les musées de l'école en Italie", in Première rencontre francophone des musées de l'école. Actes Rouen 2016 (Rouen: Le Musée national de l'éducation [Munané], 2018), 89-103; P. Dávila \& L.M. Naya, "Constitution, conservation et valorisation du patrimoine scolaire en Espagne", in Première rencontre francophone des musées de l'école. Actes Rouen 2016 (Rouen: Le Musée national de l'éducation [Munané], 2018), 77-88. The Italian article has been elaborated into another one: J. Meda, "The 'Sites of School Memory' in Italy between memory and oblivion: a first approach", History of Education \& Children's Literature 14, no. 1 (2019): 25-47. As far as Belgium is concerned, see: K. Catteeuw, "Hoe oud het nieuwe en hoe nieuw het oude is", in Op eigen vleugels. Liber Amicorum Prof. Dr. An Hermans, eds. M. D'hoker \& M. Depaepe (Antwerp: Garant, 2004), 237-248. For the Netherlands: R. van Buren, Het verschijnsel schoolmuseum in nationaal perspectief. Van praktisch en pedagogisch naar cultuurhistorisch (Scriptie [Research Paper]) (Heerlen: Open Universiteit, 2009). Recently, 
didn't just herald a change in policy priorities, including from a financial perspective; it also paved the way for various fascistoid educational schemes that increasingly started using modern mass media (such as radio) to spread their ideology. Many "national" school museums saw their significance diminish as a result, and several were simply shut down.

It is only from the 1970s-1980s onwards, when lots of small traditional schools started to disappear due to economies of scale, that a new wave of school museums started to pop up all over Europe, usually out of nostalgia for what had been lost. ${ }^{10}$ Even though the importance of culture-historical foundations was often expressly referenced as part of this, the overall picture is a little more complex than it is in education history research itself. To begin with, these museums are not so much laboratories for scientific research - however much we'd like them to be - as they are lieux de mémoire that, as I see it, simply ride the wave of whatever the remembrance industry and remembrance education expects them to be, without giving it too much thought, let alone theoretical, methodological and/or historiographic reflection and/or historical-cultural contemplation. This is because many of the initiative-takers and supporters of these school museums are former educational staff who - often consumed by romantic resonances from their own childhood - prefer to paint a rather rose-tinted view of the past. Partially out of nostalgia and longing for their former career, but also due to their allegiance to "schools" as an institution, they make every effort to highlight the benefits of the Western education system to the greatest extent possible. On top of that, they endeavour to promote this message on a completely voluntary basis, hoping and meaning that museums of this type are able to sustain themselves even without government subsidies, which are generally lacking. And that can only be viewed as a good thing from the perspective of interest in history.

However, this doesn't alter the fact that I myself remain an advocate for a greater sense of historical reality in education museums, and I

\footnotetext{
an interesting article about the then network of pedagogical museums has been published: Z. Possamai, "Ferdinand Buisson and the emergence of pedagogical museums: clues of an international movement, nineteenth century", Paedagogica Historica 57, no. 4 (2021): 381-399.

10 In our conference "stories on childhood: history, memory and research" (22-23 October 2021), this element was explicitly mentioned for the local villages in Spain by M. del Mar del Pozo Andrés, in her paper "Pedagogical museums in Spanish faculties of education: towards the future via the past".
} 
don't believe that "playing schools" or providing "historical instruction" by the role play of a blunt and old-fashioned schoolmaster - the guide keeping order in the historical reconstructed class, filled with naughty pupils - the visitors - should necessarily be part of that. My preference for a more realistic attitude is based on a clear reluctance to "use" history, even for educational purposes. After all, there are plenty of examples in the history of our field that show such use can easily lead to "misuse" or "abuse" - but that still isn't preventing colleagues from taking diametrically opposed positions in the contemporary conversation on the benefits and drawbacks of taking a historical approach in the educational sciences. In the hope that doing so will foster greater theoretical, methodological and historiographic awareness among those concerned, I'd like to delve into my opinions in this area - however limited they may be - in more detail below. In doing so, I will take a recent contribution in relation to the "educational" value of education museums as a point of departure, and I will explore to what extent my potentially controversial ideas may also be applicable to museums in general and to those about children and childhood in particular.

\section{EDUCATION MUSEUMS AS LABORATORIES FOR AN EDUCATIONAL HISTORIOGRAPHY ORIENTED TO CULTURAL HISTORY}

In the context of a Festschrift for a colleague in Germany, I recently argued that education museums, in line with their general evolution "from practical and educational to culture-historical", should ideally evolve towards becoming "laboratories" for an educational historiography oriented to cultural history. ${ }^{11}$ So, what exactly do I mean by that, and what would this look like, not just in relation to Germany, but for other countries too, even outside of Europe?

The starting point for my reflections was the international colloquium that took place five years ago in Rouen on the valorisation of educational heritage. As an introduction to the volume of conference contributions that has since been published, Jean-François Condette — who is more or less the most important educational historian in France today — wrote

${ }_{11}$ Depaepe, Über den Bildungswert. 
that education museums would do best to avoid becoming "graveyards" of "old things" that come paired with simplistic and/or overly mythological preconceptions about "schools in the olden days" 12 - an argument that I, given the position I've briefly set out above, wholeheartedly agree with. After expressing his thanks to the many "supporters" of education museums for "saving" France's educational heritage, Condette proceeds to point out that, rather than taking a purely amateuristic approach, the artefacts of education history brought together in these places deserve to be integrated into a current scientific framework. There is no need for this to involve any aspect of "presentism" in the sense of anachronism or ahistoricism, nor in the sense of using contextless historical elements in contemporary child-rearing and educational issues. On the contrary, we should pursue the exact opposite of that. By placing earlier educational ideas, theories, philosophies and practices in a culture-historical perspective, education museums have the potential to contribute to a better understanding of what is happening in the present. This leads Condette to the conclusion that education museums don't just have the potential to be useful from a research perspective, but from a teacher training perspective too - a viewpoint that is in fact shared by multiple authors publishing in Spanish too. ${ }^{13}$

To the extent that the use of education museums in teacher training helps encourage a critical perspective on the historical role played by schools and education in society, this is an idea I can certainly get behind, especially when the assignments given to students at school museums appear to coincide with "writing history", as is currently the

\footnotetext{
12 J. F. Condette, "Les musées d'éducation, leurs finalités et leurs difficultés. Conserver les traces du passé de l'Ecole pour mieux comprendre les enjeux du présent". In Première rencontre francophone des musées de l'école. Actes Rouen 2016 (Rouen : Le Musée national de l'éducation [Munaé], 2018), 7-17.

${ }^{13}$ For example: J. Ruiz Berrio, "El museísmo pedagógico en el mundo: pasado, presente y perspectivas de futuro", in I Foro Ibérico de Museísmo Pedagóxico. O museísmo pedagóxico en España e Portugal: Itinerarios, experiencias, e perspectivas. Actas, coord. V. Peña Saavedra (Santiago de Compostela: Xunta de Galicia, 2003), 55-72, 71;T. Rabazas Romero, S. Ramos Zamora and J. Ruiz Berrio, "Incidencia para la Junta de Ampliación de Estudios en la modernización de la escuela española. La innovación del material escolar a través de los manuales de Pedagogía”, in La cultura material de la escuela. En el centenario de la Junta para la Ampliación de Estudios, 1907-2007, ed. A. Escolano Benito (Berlanga de Duero: CEINCE, 2007), 138 ff.; J.M. Hernández Díaz, "Museos pedagógicos y exposiciones educativas en España en los inicios del siglo XXI", in I Foro Ibérico, 117-171, 153 ff.. In her paper at our conference "stories on childhood", M. del Mar del Pozo Andrés, "Pedagogical museums", tried to combine both: the idea of a pedagogical museum as a Laboratory for Research and as a Laboratory for Teaching. The objectives of the last section are, in her view, to cultivate a "democratic memory" as well as "building a memory of teacher identity"...
} 
case at the virtual museum of education in Andalusia, ${ }^{14}$ among others..$^{15}$ However, as this starts to incorporate more and more concrete didactic goals about one's experience of the present and the future, it seems to me that the aforementioned risk of "presentism" is not sufficiently mitigated, and the boundary with an excessively "educationalising" and/or "infantilising" approach also appears to be a highly fragile one. I will revisit this point later in the context of my discussion of childhood museums, which often seek to promote a message of peace, including in areas previously affected by war. The fact is, though, that these types of well-intentioned "peace messages" - which in principle, no one can object to, of course — are all too easily adopted and/or instrumentalised from a political and ideological perspective, as well as from an economic and money-making one; something that more or less occurred in Belgium in the wake of the "remembrance mania" surrounding the centenary of the First World War. ${ }^{16}$

"Memory" and "history" are two different things, of course. ${ }^{17}$ Even though it is not always easy to distinguish between the two in everyday practice, historiography relies much more on scientific knowledge than it does on individual or collective remembrance. With that in mind, if the artefacts in a school, school and education museums do carry some kind of message, this must surely be an unencoded one that must in any case be transformed into individual and/or collective experiences by the visitors themselves. It is for that reason that I have personally interpreted the concept of education museums as laboratories mainly as a potential locus for scientific research in educational historiography, rather than as a tool or element of whichever pedagogic training programme (such as teacher training, academic education sciences, or the vocational training of educators and so on). ${ }^{18}$ It goes without saying

14 J. L. Rubio Mayoral, "Museos pedagógicos y experiencias educativas. Apuntes de futuro", in El patrimonio histórico-educativo y la enseñanza de la historia de la educación (s.l.: Sociedad Española de la Historia de la Educación, 2009) 93-110, 96.

${ }^{15}$ At our conference "Stories on childhood", L. Daniela reflected in her paper upon "Virtual museums and their educational potential".

${ }^{16}$ See, e.g., Depaepe \& Simon, It's all about interpretation.

${ }^{17}$ In relation to education and childhood museums, see, e.g., A. Lloyd, "Institutionalized stories: childhood and national-socialism in contemporary German museum displays", Oxford German Studies 43, no. 1 (2014): 89-105, 92 ff.

18 Depaepe, Über den Bildungswert. 
that this wouldn't necessarily be detrimental to the potential educational value of a historical or historiological element, as every training programme - and especially any academic one - must primarily be based on scientific research. As I've explained, though, I want to steer well clear of any utilitarian use of history in the service of predetermined educational or training objectives to be ticked off, as it were, at the end of any mandatory work or educational visits. In my opinion, this kind of didactic stranglehold fails to do justice to the "melting pot" of personal experience, stories and memories that may arise from interaction with the objects on display, in the same way that intrusive explanations by pedantic guides can ruin the exact same encounters. As far as I'm concerned — and even though I'm more than aware that not everyone will share this point of view - it is best not to be overly patronising about the "wise" lessons history can teach us during a tour of an education museum.

As I've claimed multiple times myself in relation to educational historiography, the search for "lessons", let alone "applications" from the educational past is not all that relevant to the present. ${ }^{19}$ As I see it, the task of school or education museums does not lie in moralising the past (in the sense of forming judgement about what was "good" and "bad" about the education of yesteryear), nor in spreading some well-intentioned message or other (about the need for schools, or about their beneficial effects, for example). Instead, it lies in teaching people to think critically about the role played by child rearing and education in society. Rather than pursuing normative-pedagogical goals, and consistent with contemporary culture-historical research into the history of child rearing and education, to me, museums of education are simply places that facilitate individual cultural consumption, both by individual citizens (including young people) and by scientific researchers. That said, one of the non-premeditated (side) effects of that latter element may well be the generation and emergence of new or more detailed educational history knowledge.

For example, careful study of the items gathered in museums of education - school desks, for instance, as well as textbooks ${ }^{20}$ - may well

\footnotetext{
${ }_{19}$ See the references in note 8 .

${ }^{20}$ Cf. Escolano (Ed.), La cultura material. Our point of view in relation to school desks and textbooks is developed in, among others, F. Herman, A. Van Gorp, F. Simon \& M. Depaepe, "The school desk:
} 
lead to more detailed insight into the quasi-universal modernisation processes that occurred in Western education at large, and that research may in turn result in better understanding of everyday school culture and the ways of working that are persistently present therein (with the oft-discussed grammar of schooling as a real "textbook example"). In brief, this type of study could prise the "text" out of the many historical and spatial "contexts" to establish what actually occurred in the "black box" of classrooms and schools, in order to help provide an impetus to establish a "historic" school theory that helps us better "understand" the educational past. ${ }^{21}$ Because that past was a much more complex labyrinth than the overly simplistic use of history as a pick-and-mix jar from which we can pull arguments to serve our own, one-and-only "correct" point of view suggests - and that's before we mention the one-sidedness to which the near-constant contradiction between "old" and "new" inevitably leads, and the sweeping under the carpet of everything that doesn't fit that view. The wholesale seizure of everything that vaguely resembles "funtime pedagogy" and "deschooling" to prove once and for all that standards have fallen as a result of the involvement of educational reformers and "iconoclasts" serves as just one example of the latter. ${ }^{22}$

Whether the additional and refined knowledge potentially generated by education museums about the more complex evolution of educational practice will lead to better educational practice in the present certainly remains to be seen, but it will nevertheless advance the general education of the people involved, whatever stage they are at. As I see it, we wouldn't even need to develop any special guided tours or didactic packages to

from concept to object", History of Education 40, no. 1 (2011): 97-117; M. Depaepe, F. Simon \& P. Verstraete, "Valorising the Cultural Heritage of the School Desk Through Historical Research", in Educational Research: Material Culture and Its Representation, eds. P. Smeyers \& M. Depaepe (Cham/ Heidelberg/New York/Dordrecht \& London: Springer, 2014), 13-30; M. Depaepe, "Studying the history of education with textbooks: some reflections from our own research experiences", in Les manuels scolaires dans l'histoire de l'éducation : un enjeu patrimonial et scientifique, dir. M. Berré, F. Brasseur, C. Gobeaux \& R. Plisnier avec la collaboration de B. Bouchet (Mons: CIPA, 2013), 111-121; A. Van Gorp \& M. Depaepe (Hrsg.), Auf der Suche nach der wahren Art von Textbüchern (Bad Heilbrunn: Verlag Julius Klinkhardt, 2009).

${ }^{21}$ See, e.g., M. Depaepe, F. Simon, M. Surmont \& A. Van Gorp, "Menschen in Welten - Ordnungstrukturen des Pädagogischen auf dem Weg zwischen Haus und Schule”, Zeitschrift für Pädagogik 52, Beiheft (Juni 2007): 96-109.

22 E.g., R. Feys, N. Gybels, P. Van Biervliet \& S. Brasseur, "Vlaams onderwijs al lang mismeesterd. Onderwijskrant-memorandum 2019. Verzet/lippendienst leerkrachten temperde ontscholing/niveaudaling", Onderwijskrant 189 (2019): 2-21. 
achieve that. After all, we cannot plan the effects of the non-patronising confrontation of visitors with the material on show at carefully considered exhibitions, both permanent and temporary. We can only hope that the range of intelligently selected artefacts from the history of child rearing and education enables visitors to genuinely connect, causing an "aha" moment for the latter that facilitates a liberating, engaging and sometimes healing dialogue with the past. ${ }^{23}$ Sexual education is one area in which this might happen, for example. Throughout history, this has been a topic of great concern to teachers and parents, even though generally speaking, time has caught up with their woes. ${ }^{24}$ Today, the fact that in 1948, a rhetoric teacher from the college in Roeselare (at the time the "preparatory seminary" for priest education in West-Flanders) was refused permission by his superiors to take final-year students at Brussels to an impressive retrospective exhibition on the work of Peter Paul Rubens "because it contained too much nudity" 25 cannot fail to put a smile on our faces, for example. A more upsetting example can perhaps be provided in the form of the arguments put forward for a significant period of time by catholic elements in society in favour of maintaining gender inequality in university education. The fact that Belgian bishops, the most prominent among them Cardinal Van Roey around 1920, believed that women with a university degree were neglecting their duties as mothers and wives may sound shocking to our ears, but these events become even more lamentable when we realise that in the end, they changed their mind purely for pragmatic reasons: the fear that their catholic university would lose students to its non-catholic competitors. ${ }^{26}$ This doesn't necessarily have to lead to a moral (and at the same time, ahistorical) condemnation of former (catholic) educational practices,

\footnotetext{
${ }^{23}$ We have already used this example in: Depaepe \& Simon, It's all about interpretation, as well as in: Depaepe, Über den Bildungswert.

${ }^{24}$ See the thematic exhibition in Ypres about the history of sexual education: C. Steverlynck, with the cooperation of D. Dendooven \& L. Verschuren, Het grote geheim. Omgaan met lichamelijkheid en seksualiteit in opvoeding en onderwijs tijdens de $20^{\text {ste }}$ eeuw (s.l., s.d., 2010) [=Ypres, Stedelijk Onderwijsmuseum, 2010].

25 J. Srobbe, 200 jaar dichters, denkers en durvers. Het Klein Seminarie van Roeselare. Biografie van een college (Tielt: Lannoo, 2006), 422.

${ }^{26}$ Over blauwkousen en blokbeesten. Precies honderd jaar geleden deden de eerste meisjesstudenten hun intrede in Leuven, Sonar. KU Leuven-magazine 1, no. 2 (2020-2021): 85-86. For more context, see L. Nys \& J. Tollebeek, The city on the hill: a history of Leuven University, 1968-2005 (Leuven: Leuven University Press, 2006).
} 
but it must surely lead to better understanding of the spirit of that age, and consequently, to more objective (or self-depreciative?) "wisdom", possibly going hand in hand with postmodern irony about the ways in which people worried about education and the upbringing of their children in the past. ${ }^{27}$

So, do the considerations I've discussed above in relation to school and education museums apply all the same to the broader context of museums on children and childhood — an area that I'm happy to admit I'm less familiar with? Or are these types of museums so specific that separate and/or additional educational objectives can and must be pursued?

\section{A PLEA FOR MORE CULTURE-HISTORICAL CONTEMPLATION AND LESS EDUCATIONAL STRATEGY IN THE MUSEUM REPRESENTATION OF CHILDREN AND CHILDHOOD}

When combing through potentially relevant literature I came across more or less by chance during coronavirus times, I found little to back up the idea of a parallel evolution between museums of childhood and those of education. As far as I was able to establish, museums about children, contrary to education museums, did not come about as "didactic" institutions during the 19th century. ${ }^{28}$ Instead, they had more or less purely "historical" intentions right from the start, in the sense that they intended to represent the past. ${ }^{29}$ This also applies to contemporary displays of childhood, even for periods, like national-socialism in Germany, about one is generally inclined to "learn" something. ${ }^{30}$

\footnotetext{
${ }^{27}$ Cf. Depaepe, Why even today.

${ }^{28}$ Which of course does not mean that these museums did not appropriate an educational task in the line of the Enlightenment thinking - an argument I will deal with further on. See, e.g., N. Prior, Museums and Modernity: Art Galleries and the Making of Modern Culture (Oxford/New York: Berg, 2002): the visitor of the $19^{\text {th }}$-century museum was imagined to be an ideal citizen searching for the wishful moral values and norms through a civilizing experience, and the "less civilized" visitors had to be educated through viewing the collections. See, in this respect also: M.J. Milligan \& A. Brayfield, "Museums and childhood. Negotiating organizational lessons", Childhood 11, no. 3 (2004): 275-301, 277.
}

29 See, e.g., C. Murken, "Das Kind in der Kunst als Spiegel des gesellschaftlichen Wandels" in Kinder des 20. Jahrhunderts. Malerei. Skulptur. Fotografie, hrsg. C. Murken, K. Weschenfelder \& B. Schad (Cologne: Wienand Verlag, 2000), 8-28.

${ }_{30}$ Cf. A. Lloyd, "Institutionalized stories: Childhood and national socialism in contemporary German museum displays", Oxford German Studies 43, no. 1 (2014): 89-105, 90: "the desire to secure a narrative of 'authentic' experience [...] which for many offer a more personal view on history". For 
Could this be something to do with the somewhat outdated, but still omnipresent division of tasks in many European countries between historically oriented "pedagogues" and "historians" interested in pedagogy, in which the former mainly devote themselves to the history of education (in primary schools, which are often the core focus of education museums) alongside the intellectual history of pedagogical ideas and the emerging science(s) of pedagogy, while the latter also often venture into the history of childhood and youth in addition to the history of universities? Even though this distinction has generally not been all that explicit over the years, it can easily be demonstrated, using the historiographical development I've personally witnessed in Flanders from the 1970s onwards, for example. ${ }^{31}$

One thing that stands out as part of this - and that may strike us as somewhat unexpected - is that pure historians, in their quest for attention among a broader audience, have by no means shied away from associations with contemporary developments. The symbolic year of 1968, for example, which saw student protests across the globe that led to a political crisis in Flanders resulting in the split of the University of Leuven (and later the University of Brussels) into independent Dutch and French-language institutions, has served as the starting point and/or basis of comparison for historical studies of past student movements on multiple occasions. ${ }^{32}$ Even classicists couldn't resist the temptation to associate the so-called authority crisis of the late 1960s with educational issues in Ancient History, with twentieth-century terms such as "dandy" and "greaser" used to describe the "rebellious" and "scruffy haired" youth of those times. ${ }^{33}$

\footnotetext{
an analogous line of thought, see A.W. Moore, "Children We Have Lost: Diaries, Memoirs, and Museum Displays of Childhood and Youth in Wartime Japan", Cultural and Social History 17 (2020): 715-729: Violence, Hunger, and Play have coloured the childhood generation after 1945 - a childhood "without toys", but nevertheless with some experienced happiness...

${ }^{31}$ See F. Simon, "Education", in Historical Research in the Low Countries, eds. N.C.F. van Sas \& E. Witte (The Hague: Nederlands Historisch Genootschap, 1992), 58-67.

32 E.g., L. Vos, "Traditie als bron van vernieuwing. De katholieke studentactie in Vlaanderen, 19551975”, Bijdragen tot de Eigentijdse Geschiedenis, no. 8 (2001): 133-179; and more specifically, L. Vos, Bloei en ondergang van het AKVS. Geschiedenis van de Katholieke Vlaamse Studentenbeweging, 19141935 (Leuven: Davidsfonds, 1982) vol. I, 27.

33 E.g. E. Eyben, De ontstuimigen. Jeugd en ondeugd in het Oude Rome (Kapellen/Kampen: DNB-Uitgeverij Pelckmans/Uitgeverij Kok Agora, 1987); C. Laets \& J. Strubbe, Jeugd in het Romeinse Rijk. Jonge jaren, wilde haren? (Leuven: Davidsfonds, 2008).
} 
And that brings us neatly to one of the most fundamental problems of the historical profession - a problem that I've been struggling with right since the earliest days of my career: to what extent can and should we use contemporary concepts (generally borrowed from other humanities subjects with nomothetic ambitions, and geared towards universal applicability as a result) to describe, clarify and explain specific historic situations? Can we, for example, refer to the educational practices of 19th-century colleges as so-called "cross-border behaviour" - as I read in a recent interpretation of the life and work of Guido Gezelle, Flanders' most famous priest-poet - because of the "consciousness-restricting" stranglehold of the catholic pedagogy of the time and the "sublimated homoerotic fantasies" and "proselytism" of the pedagogue in question? ${ }^{34}$ Or do we need to approach the history of education on its own terms and in accordance with its own concepts in order to assess it in the most accurate way possible, and more specifically, in a legitimate way? This latter attitude is often laughed out of the room by contemporary authors, to whom "seeing the past as the past" - in the context of the renovation of the Africa-Museum in Tervuren, for example — is nothing more than an "absurdity of privilege". ${ }^{35}$

Without wanting to anticipate the potential conclusions of this article, let alone offer a definitive solution to the methodological paradox of presentism - after all, we have no option but to write history from our present perspective - a degree of caution and nuance appears to be welcome here. Insofar as understanding is concerned, I believe a contemporary conceptual framework can undoubtedly come in useful to clarify matters, ${ }^{36}$ but using those same conceptual keys to assess or condemn the past strikes me as one bridge too far. The history of pedagogy (or how we deal with children) absolutely shouldn't serve as a moral court in which actors from the past are called to account, especially not on the basis of contemporary norms and standards. ${ }^{37}$ On top of that, the

\footnotetext{
${ }^{34} \mathrm{~J}$. Vermeulen, Gezelle in context: taal, macht en identiteit ([Brugge]: Guido Gezellekring, 2021), 340-341.

35 J. Olyslaegers, Is het van ons? De Standaard (10 April 2021) DSL 3. For a more profound view about the "new" Africa Museum in Belgium, see M. Zana Etambala, "A Virtual Visit to the Renovated Royal Museum for Central Africa. Two Major Challenges: Decolonization and Africanization", in Folds of Past, eds. Van Ruyskensvelde, et al., 147-174.

36 Which is also apparent from the title of my article and the use of the concept of "educationalisation".

37 See, in this respect, the first (and methodological) chapter of M. Depaepe et al., Order in Progress. Everyday Educational Practice in Primary Schools: Belgium, 1880-1970 (Leuven: Leuven University Press, 2000).
} 
fashionable concepts of the present and the trendy labelling of historical situations these give rise to often generalise issues (and serve as a reductionistic element in terms of their specific features) to such a degree that we must ask ourselves to which extent they remain applicable to individual circumstances. To name just one example: I barely recognise myself in the popular literature about the "golden" or "revolutionary" 1960 s, even though I actually lived through that period as a child, ${ }^{38}$ and later as an adolescent, and the same applies to the 1970s. ${ }^{39}$

The fact that this kind of stereotyping may have an impact on the collection, categorisation, periodisation and visual presentation of material in museums about childhood and youth is an obvious conclusion. ${ }^{40}$ As a consequence, it seems advisable for these museums to keep the terminology they use as broad and open as possible on the one hand, ${ }^{41}$ while sticking as closely as possible to the latest relevant historical research on the other hand..$^{42}$ Clearly though, that's easier said than done. First of all, there is no simple linear experience of time in the sense that the past is past, the present now, and the future something to come. ${ }^{43}$ In our projects we often unintentionally drag our past along and our plans for the future also play a role in our daily thinking and acting. Therefore, museums of "childhood", which at first sight appear to concern themselves solely with "historical" content (even though, on closer inspection, "childhood", "youth", "young people" and so on are all social constructs

\footnotetext{
${ }_{38}$ P. Damen, Jong in de jaren '60. Tijdsbeeld van een generatie (Utrecht/Antwerp: Uitgeverij Kosmos, 1992), 9.

39 E. van Eeden \& P. Nijssen, Jong in de jaren '70 (Utrecht/Antwerp:, Uitgeverij Kosmos, 1993), 71 ff.

${ }^{40}$ See, e.g., the wall representing the so-called "golden" sixties at the museum of memorial Charles de Gaulle in Colombey-les-deux-églises (Champagne, France): https://www.champagne-ardennen-toerisme.nl/plaatsen-om-te-bezoeken-5/memorial-charles-de-gaulle-678310\#lg=1\&slide=9 (retrieved on $30^{\text {th }}$ September 2021).
}

${ }^{41}$ A well-balanced example can be found in my view in: S. Jovanović, "Memories Taken Over. The Photo Archive of the Museum of Childhood", in Memories Taken Over. The Photo Archive of the Museum of Childhood, V. Perić, (Belgrad: Museum of Applied Art, 2009), $7 \mathrm{ff}$.

${ }^{42}$ For the so-called "vertigo" years, see, e.g., Ph. Blom, The Vertigo Years. Change and Culture in the West 1900-1914 (London: Weidenfeld \& Nicolson, 2008). In the Dutch edition of 2017 (Amsterdam, De Bezige Bij) it is called: the "dizzying" years... this same "stereotyping "also applies to the "gay" twenties, and the "temptation of the masses" during the thirties, see e.g. the exhibition in Brussels from 25 February till 5 June 1994 in the then called ASLK-building: De Jaren '30 in België. De massa in verleiding (Brussels: ASLK \& Ludion, 1994).

${ }^{43}$ Fendler, Critical Powers. 
instead of historical facts), ${ }^{44}$ are increasingly positioning themselves as indispensable in the present. In doing so, they often rely on their "educational" tasks - and that automatically means they must deal with contemporary educational values and standards. In fact, this focus on the educational aspect shouldn't come as a surprise. In a society in which, as we've discussed, the "modern" ideology of utility (i.e. with its roots in the Enlightenment) continues to be held in high esteem, there is a constant clamour for "quality indicators" to measure the importance and effectiveness of the museums in question - or in other words, their right to exist. Of course, visitor numbers would appear to be most obvious criteria to use to do so, as museums cost a lot of money, and income from visitor tickets is often viewed as a reasonable level of compensation for the money put into them by taxpayers via government subsidies. Is it true that "museums of the 21 st century will need to be more flexible than ever" and that "the long term sustainability of museums will depend on their ability to diversify everything: funding, teams, audiences, content and approach"? Is it true that "the museum industry will need to innovate as quickly as other industries", and that "flexibility, networking and innovation will be [the] key for winning over audiences"? 45 Or is it the aftermath of a dominant neoliberal discourse that pays little attention to the cultural learning effects of museums? As Frank Simon argued "it looks like the winner-takes-all economy, liberalisation, the adoption of a neoliberal logic, with art flippers ready to pounce, is set to continue for quite some time". ${ }^{46}$

That said, this striving for "profitability" (and the associated drive for greater "attractiveness", which is deemed to bring in greater visitor numbers) also has unintended consequences for the design element of museums. One example is the dogma of digitisation, which aims to

\footnotetext{
${ }^{44} \mathrm{Cf}$., e.g., the romantic idyll of the innocent child which played a significant role not only in the museum representation of the child, but also in art and in educational politics, even in turbulent times of dictatorial regimes, see, among others: K. Straube-Heinze \& C. Heinze, Lesen Lernen im National-Sozialismus. Theoriekonzepte - Kindheitsbilden - Bildungspolitik (Bielefeld: Transcript Verlag, 2021); B. Schad, "Kindlichkeit als Metapher für Ursprünglichkeit. Die Kindbildnisse des Expressionismus", in Kinder, Murken, Weschenfelder \& Schad, 29-41; J. Kinchin \& A. O'Connor (Eds.), Century of the Child. Growing by Design, 1900-2000 (New York: MOMA, 2012) 2c, 50 \& 70.

45 J. Halilović, "The War Childhood Museum: Creation and Principles", Museum International 71, no. 1-2 (2019): 124-131, 131.

${ }^{46}$ F. Simon, "Afterword: inexhaustible cultural learning", Paedagogica Historica 53 (2017): 342-346, 344.
} 
improve interaction with the public. It certainly is possible to use digital aspects intelligently, and they can certainly open up interesting new avenues for innovative insights and knowledge - there are countless examples of that, especially in relation to so-called "virtual" exhibitions and tours ${ }^{47}$ - but it sometimes appears that policymakers and politicians have lost all sense of proportion in this context; something that can perhaps also be said in relation to the wider world of education. ${ }^{48}$ As long as more computers and more IT equipment are being introduced, everything must surely be going swimmingly, right? And, as a museological consequence: relying on "interactive pedagogy", "to capture children's attention and make a lasting impression". ${ }^{49}$ At the start of my time working as a consultant in Ypres, the former city archivist repeatedly implored the local councillors not to turn the In Flanders Fields Museum, more on which in just a moment, into an electronic theme park. Luckily, it never quite got to that point, but I also can't quite shake the impression that the development of all kinds of didactic packages (brimming with worksheets, fill-in-the-blank exercises, search challenges and other games) both in Ypres and elsewhere aren't exactly helping to slow down "educationalisation" (by which I'm not just referring to the increasing importance and influence of pedagogy on society, but also to the improper use thereof) and the associated "infantilisation". ${ }^{50}$ Quite the contrary, in fact. ${ }^{51}$ As far as I'm concerned, there is no need whatsoever for museums about children to organise workshops to combat obesity, for example. ${ }^{52}$

\footnotetext{
${ }_{47}$ Just to give one example, see: https://www.youtube.com/watch?v=xPVOIiwReG8 about the V\&A [Victoria \& Albert] Museum for childhood, which is currently rethinking its approach and collections in view of its $150^{\text {th }}$ anniversary in 2022 , see, in this respect, https://www.vam.ac.uk/info/transforming-the-va-museum-of-childhood\#new-programmes-and-galleries (retrieved on September 30, 2021).

${ }^{48}$ See, e.g., the website of the Flemish minister of education, Ben Weyts, who promises that in the coming two years a total of $€ 375$ million will go to ICT devices, ICT training courses and ICT coordinators, see: https://www.benweyts.be/Scholen-kunnen-beginnen-aan-Digisprong- (retrieved on September 30, 2021).

${ }_{49}$ Milligan \& Brayfield, "The War Childhood Museum”, 290.

${ }_{50}$ The analogy with the process of "medicalization" is srriking. See, among others, M. Depaepe, F. Herman, M. Surmont, A. Van Gorp \& F. Simon, "About Pedagogization: From the Perspective of the History of Education", in Educational Research: The Educationalization of Social Problems, eds. P. Smeyers \& M. Depaepe (Dordrecht: Springer, 2008), 13-30.
}

${ }^{51}$ Milligan \& Brayfield, "The War Childhood Museum", 277: "In modern Europe and the US, museu$\mathrm{ms}$ and art galleries historically have claimed an educative purpose".

${ }^{52}$ E. Koukos \& S. Folta, "Involving Cultural Institutions in the Prevention of Childhood Obesity: The Boston Children's Museum's GoKids Project”, Journal of Nutrition Education and Behavior 42 (2010): 
We have other institutions available to deal with that; hospitals strike me as the obvious example.

In itself, the interest shown by museums in the educational, historically speaking, is just as much a consequence of the "modernisation" of society, in which the role of museums, in line with Enlightenment principles, is seen as a form of "popular education". Just like schools, museums were institutions with an educational purpose that were expected to bring the dominant value systems of the time closer to the people. ${ }^{53}$ Even though those values might have changed beyond recognition today, this doesn't prevent the fact that museums, partially with a view to substantiating the services they provide to society, are almost obliged to draw up a mission statement in which they set out their duties towards contemporary society. ${ }^{54}$ A pedagogic/didactic element is usually front and centre in this, as the more children visit museums (whether or not as part of school trips), the better: "what's learned in the cradle is carried to the tomb", their thinking goes. As a result, these mission statements usually also list a set of objectives to be pursued, which — just like with school inspections - can be "ticked off" one after the other during the inevitable regular assessments by some visiting committee or other working for those who put their hands in their pockets to keep the place going.

The evolution so-called "war museums" have gone through seems to be a good example of how significantly educational aspirations have changed. While immediately after the First World War, these museums emphasised civic education, patriotism, nation building and the like, their agenda - especially in the last few decades of the 20th century has shifted towards "peace education", which assumes tolerance, understanding and even empathy for the other party in a conflict rather

427-429. The article also contains disturbing (writing?) errors, it speaks about "the popular education theories of Paulo Friere (sic)", which is repeated in the literature list.

${ }^{53}$ See note 26.

${ }^{54}$ See, e.g., how the National Museum of African American History and Culture approaches conversations on "race" with young children and their families and teachers: A. Forgerson Hindley \& J. Olsen Edwards, "Early Childhood Racial Identity - The Potential Powerful Role for Museum Programming", Journal of Museum Education 42, no.1 (2017): 13-21; or how "sites of remembering" can be best used as "alternative educational spaces": M.S. Merry \& A. Schinkel, "What is an appropriate educational response to controversial historical monuments?", Journal of Philosophy of Education 40 (2021): 484-497. 
than hatred of the enemy. ${ }^{55}$ From that perspective too, the In Flanders Fields Museum in Ypres can be viewed as a typical example. As we've said, these are very worthwhile goals in a society that longs for peace, but that keeps doing everything it can to maintain inequality between continents and countries by supplying them with arms, among other things... The City Secretary of Ypres described the opening ceremony of the "peace" museum on April 251998 with representatives of "martyrs cities" from all-over the world as follows: "correct representation of history [sic] makes us aware of mistakes made in the past. This kind of education is the key to opening the eyes to a positive attitude and to love. This contrasts with the too simple solutions of extremists. The economically powerful arms industry is unethical and must be curbed for its destructiveness [...] Human rights should be the same for everyone in the world. It doesn't matter if you are black or white, male or female, old or young, believer or unbeliever [...] Use those differences so that we can appreciate each other and live better together" ${ }^{56}$

However, it is obvious that from those beautiful, but unfortunately naive expectations, not much has been realised in the meantime, even for those, among us, who do not follow the portions of doom in the news on a daily basis. And that's why things aren't always that clear cut, especially in places where the wounds of recent conflicts have not yet sufficiently healed. Is it possible to fully erase all traces of the Balkan Wars in the former Yugoslavia through peace education? Or would the voice of political pressure groups - who may also be in control of funding - be too prevalent in the representation of child suffering? And what about the processing of past wars in Asia, in Japan and/or in Indonesia, to name just a few additional examples of situations in which we've got some level of insight?57 The fact that policymakers often seek to generate political capital through

\footnotetext{
${ }_{55}$ Cf., e.g., T. Takševa, "Building a Culture of Peace and Collective Memory in Post-conflict Bosnia and Herzegovina: Sarajevo's Museum of War Childhood”, Studies in Ethnicity and Nationalism 43, no. 1 (2018): 3-18. In the meantime, "Historical Memory Education for Peace" itself has become a new "field" of research, see: J. Corredor, M.E. Wills-Obregon \& M. Asensio-Brouard, "Historical memory education for peace and justice: definition of a field", Journal of Peace Education 15 (2018): 169-190.

${ }^{56}$ Cf. J. Breyne, Ieper. Portret van een stad (Tielt: Lannoo, 2000), 111.

${ }^{57}$ Moore, Children we Have Lost; Halilović, The War Childhood Museum; Takševa, Building a Culture of Peace; Corredor, Wills-Obregon \& Asensio-Brouard, Historical memory education... Concerning Indonesia, see D. Van Reybrouck, Revolusi. Indonesië en het ontstaan van de moderne wereld (Amsterdam: De Bezige Bij, 2020).
} 
remembrance education is widely known, even though they are occasionally forced to admit — to their regret — that they may have misjudged certain historic situations. The recent commotion in Flanders surrounding a statue of a beehive put up as a monument on "Briviba" square (Latvian for "freedom") in Zedelgem serves as a perfect example of the latter. The statue was meant to commemorate the 12,000 Latvian soldiers who fought with the Germans against the Russians during the Second World War, with survivors taken as prisoners of war near the village. ${ }^{58}$ Once again, this proves that it is extremely tricky for Flemings to fully identify with the historical complexity of nations like Latvia, which were repeatedly occupied under various manifestations of imperialism. ${ }^{59}$ Needless to say, this conclusion makes the key question of this brief essay about my role in the aforementioned project by my colleague Iveta Kestere even more pressing.

\section{WHAT CAN WE DO?}

Of course, cynical immobilism is by no means the intended conclusion of the more or less parallel reservations I have expressed in the previous two sections in relation to both education museums and museums about children. They are not anti-pedagogical, and neither do they advocate a curbing of museum projects about children, their upbringing and their education. What I am seeking to do in this brief contribution, fully in line with earlier publications, is to argue for more "historical" level-headedness. As a minimum, that involves the following two aspects: alignment with the research in the cultural historiography of child-rearing and education, children and young people on the one hand, and more theoretical-methodological self-awareness on the other. In fact, I believe that latter aspect may be the only way to deal with the paradox of presentism ingrained in every "historiographical operation". ${ }^{60}$ This is borne out by into this point any deeper here as a result.

\footnotetext{
${ }^{58}$ See, e.g., http://www.belgians-remember-them.eu/zedelgem.php (Retrieved on 4 October 2021).

${ }^{59}$ See, e.g., D. Bleiere, I. Butulis, I. Feldmanis, A. Stranga \& A. Zunda, History of Latvia. The $20^{\text {th }}$ Century (Riga: Jumava, 2006); as far as the dealing with cultural heritage and the development of educational sciences are concerned, see, among others: I. Kestere, "The school theatre as a place of cultural learning: the case of Soviet Latvia (1960s-1980s)", Paedagogica Historica 53 (2017): 318341; I. Kestere, Z. Rubene \& I. Ozola, "Educational Sciences Between 'Real' Moscow and the 'Imaginary' West: The Case of Latvia (1989-1999)", in Folds of Past, Van Ruyskensvelde et al., 267-282.
}

${ }^{60}$ After M. de Certeau, L'Écriture de l'histoire (Paris : Gallimard, 1975), 8. 
However, I do briefly want to touch upon one aspect in this context, as it has direct repercussions on the selection of the material offered in museums. ${ }^{61}$ That aspect is the suggestion to stay as close as possible to our sources, as I believe that this presents the ideal way to keep (re)discovering both the normal and the everyday of the past in a way that cuts right through the normativity of educational, political, religious and ideological contexts. Examples of this are legion, both for written sources and visual ones. ${ }^{62}$ Out of the countless options, I've decided to select just one; an example that is very close to my heart, as we used it in Ypres during our final themed exhibition: "Going to school in times of war". ${ }^{63}$ The example in question is a photo dating back to 1918 , from the archives of the Imperial War Museum in London (see the image enclosed): a child from the Tournai region, on the run from the misery of war, but with a beaming smile on her face nonetheless, as she's just been given a loaf of bread by a British soldier. Even though this may well be a case of staged wartime propaganda, I believe the confrontation with the spontaneous smile on the child's face opens up genuine learning opportunities for both children and adults in relation to shaping their attitude towards war and peace. After all, the things that stick with us through time generally aren't the result of carefully considered didactic and/or pedagogic "strategies" - a word that, not entirely coincidentally, has been borrowed from the military realm and is aimed at "conquest" and the "imperialist" spread of opinions and attitudes deemed correct by those in charge. True education - and I'd even go as far as to use the heavily loaded term Bildung here ${ }^{64}$ - occurs as the result of an "open"

\footnotetext{
${ }^{61}$ See, e.g., S. Brookshaw, "The Material Culture of Children and Childhood. Understanding Childhood Objects in the Museum Context", Journal of Material Culture 14 (2009): 365-383.

${ }^{62}$ E.g. in the context of peace and war: Beyond the Battlefields: Käthe Buchler's Photographs of Germany in the Great War \& The University of Birmingham and the Great War (Birmingham: s.p., 2017). Also the Museum of Ypres, in Flanders Fields, did a good job in publishing original [i.c. written] sources about the Great War, cf. P. Chielens \& P. Troch (Eds.), De Geschreven Oorlog (Amsterdam/ Antwerpen, Manteau/De Bezige Bij/WPG Uitgevers België: 2016). In the context of the history of education, as such, the catalogue of the exhibition Madrid, Ciudad educadora 1898/1938 (Madrid: Museo de Historia de Madrid, 2019) is really outstanding.

${ }^{63}$ R. Barbry, J. Dewilde, M. Depaepe, F. Simon, E. Goerlandt, A. Vandenbilcke \& M. Verplaetse (Eds.), Naar school zelfs in oorlogstijd? Belgische kinderen lopen school, 1914-1919 (Ieper: Stedelijke Musea, 2015), 128.

${ }^{64} \mathrm{Cf}$. H. von Hentig, Ist Bildung nützlich?, in Metamorphosen der Bildung. Historie - Empirie - Theorie, hrsg. E. Keiner, K.-P. Horn, H. Kemnitz, U. Mietzner, U. Pilarczyk, J. Schuch \& N. Welter (Bad Heilbrunn: Klinkhardt, 2011), 395-412.
} 
dialogue, free from any power structures and not aimed at imposing a certain specific point of view, but merely acting as an invitation to explore a different perspective of which the subject is insufficiently aware. Consequently, the results of true education are often unpredictable: what exactly the experience of Bildung does to those who go through it depends in the first instance on visitors themselves, who "sample" and eventually "consume" the material offered in museums (even though that latter verb most likely possesses way too much of a commercial connotation in this context) and not on the institution offering the material, its curators, its museum specialists, its content consultants or whoever else. That team of people is certainly capable of producing an exhibition, but it cannot plan the effects that a well prepared exhibition will have in the personal life of visitors, and it certainly can't guarantee its success by waving a magic wand of carefully considered learning objectives, cleverly compiled learning packages, crystal-clear explanations, patronising commentary and so on. Going back to the quotes I used at the top of this article, it certainly cannot be excluded that, as far back as the second half of the seventeenth century, Jean de La Fontaine already had a hunch along the same lines.

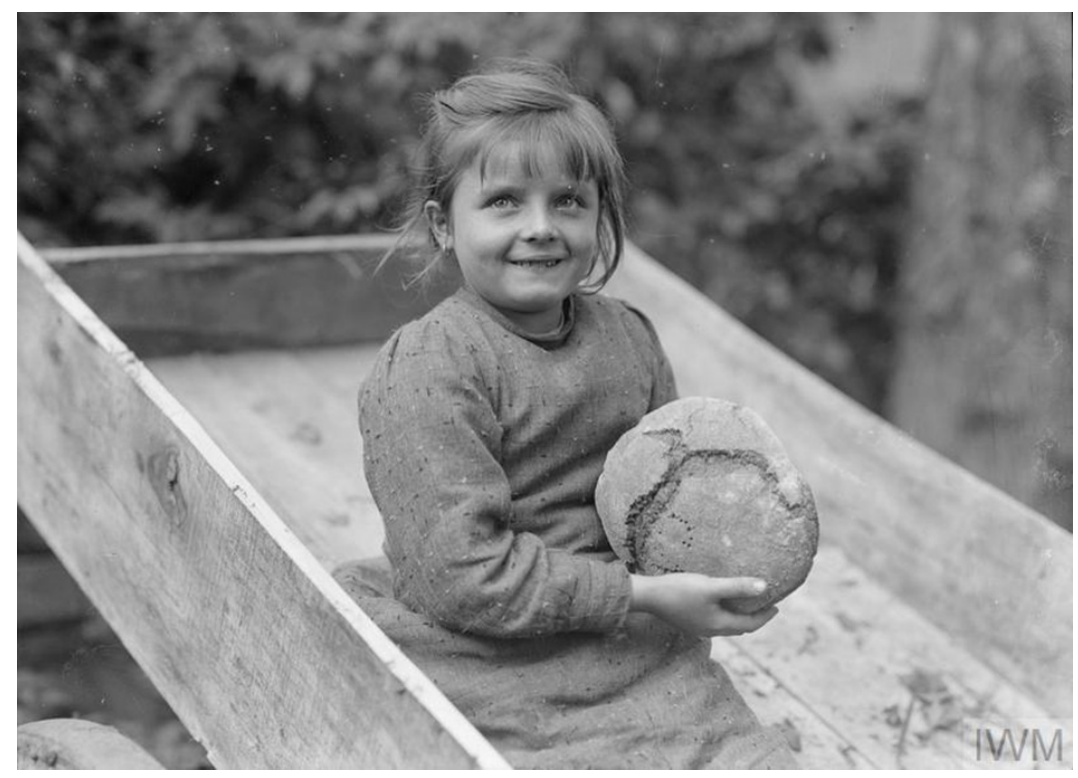

Illustration: Refugee child being cared for by the British Army. Near Tournai, 26 October 1918.

See also: https://www.iwm.org.uk/collections/item/object/205245364 May be used without permission for academic purposes. 


\section{Note on the author}

Marc Depaepe (1953) is emeritus professor of history of education at the KU Leuven, where he was deputy chancellor between 2013 and 2017. Since 2005 co-editor-in-chief of Paedagogica Historica. Former president of the International Standing Conference for the History of Education (1991-1994) and member of the International Academy of Education (2012-). Member of several other international societies and editorial boards related to educational historiography. Published and co-published abundantly on the history of educational and psychological sciences in Europe and the United States; the history of schooling in Belgium (especially primary education); the theory, methodology, and historiography of the history of education as a discipline; the history of colonial education, especially in relation to the former Belgian Congo (1908-1960). The outcome of his research has been published in several languages. In 2015 he was awarded an honorary doctorate at the University of Latvia in Riga, at which he is, since 2019, engaged as a leading researcher. His museum-expertise is built on the experience as scientific adviser for the municipal Education Museum in Ypres, during the whole period of its existence (1991-2017), while typical for his history of childhood research is its theoretical foundation, which is, among other things, rooted in concepts like the ongoing educationalisation and infantilization of childhood (closely related with processes of "modernization").

\section{REFERENCES}

Aldrich, R. Lessons from History of Education. The selected works of Richard Aldrich. London/New York: Routledge, 2006.

Ascenzi, A., M. Brunelli and J. Meda. "Représentation du passé scolaire dans les musées de l'école en Italie". In Première rencontre francophone des musées de l'école. Actes Rouen 2016. Rouen: Le Musée national de l'éducation [Munaé], 2018.

Barbry, R., J. Dewilde, M. Depaepe, F. Simon, E. Goerlandt, A. Vandenbilcke and M. Verplaetse (Eds.). Naar school zelfs in oorlogstijd? Belgische kinderen lopen school, 1914-1919. Ieper: Stedelijke Musea, 2015.

Bleiere, D., I. Butulis, I. Feldmanis, A. Stranga and A. Zunda. History of Latvia. The 20th Century. Riga: Jumava, 2006.

Blom, Ph. The Vertigo Years. Change and Culture in the West 1900-1914. London: Weidenfeld \& Nicolson, 2008. 
Breyne, J. Ieper. Portret van een stad. Tielt: Lannoo, 2000.

Brookshaw. "The Material Culture of Children and Childhood. Understanding Childhood Objects in the Museum Context". Journal of Material Culture 14 (2009): 365-383.

Bühler, J. Ch. Von. Die gesellschaftliche Konstruktion des Jugendalters. Zur Entstehung der Jugendforschung am Beginn des 20. Jahrhunderts. Weinheim: Deutscher Studien Verlag, 1990.

Buren, R. van. Het verschijnsel schoolmuseum in nationaal perspectief. Van praktisch en pedagogisch naar cultuurhistorisch (Scriptie [Research Paper]). Heerlen: Open Universiteit, 2009.

Catteeuw, K. "Hoe oud het nieuwe en hoe nieuw het oude is". In Op eigen vleugels. Liber Amicorum Prof. Dr. An Hermans, edited by M. D’hoker \& M. Depaepe, 237-248. Antwerp: Garant, 2004.

Certeau, M. de. L'Écriture de l'histoire. Paris: Gallimard, 1975.

Chielens, P. and P. Troch (Eds.). De Geschreven Oorlog. Amsterdam/Antwerpen, Manteau/De Bezige Bij/WPG Uitgevers België: 2016.

Condette, J.-F. “Les musées d'éducation, leurs finalités et leurs difficultés. Conserver les traces du passé de l'Ecole pour mieux comprendre les enjeux du présent”. In Première rencontre francophone des musées de l'école. Actes Rouen 2016. Rouen: Le Musée national de l'éducation [Munaé], 2018.

Corredor, J., M.E. Wills-Obregon and M. Asensio-Brouard. "Historical memory education for peace and justice: definition of a field”. Journal of Peace Education 15 (2018): 169-190.

Damen, P. Jong in de jaren '60. Tijdsbeeld van een generatie. Utrecht/Antwerp: Uitgeverij Kosmos, 1992.

Dávila, P. and L.M. Naya. "Constitution, conservation et valorisation du patrimoine scolaire en Espagne”. In Première rencontre francophone des musées de l'école. Actes Rouen 2016. Rouen: Le Musée national de l'éducation [Munaé], 2018.

Depaepe, M. and F. Simon. “Educação, Património Cultural na Bélgica: Investigação consistente espera por iniciativas museológicas”. In Educação e Património Cultural: Escolas, Objetos e Prácticas, edited by M. J. Mogarro, 73-92. Lisboa: Edições Colibri, 2015.

Depaepe, M. “Au bas de la liste des priorités? Quelques réflexions personnelles sur le traitement du patrimoine scolaire en Belgique”. In Première rencontre francophone des musées de l'école. Actes Rouen 2016, 65-75. Rouen: Le Musée national de l'éducation [Munané], 2018.

Depaepe, M. "How should history of education be written? Some reflections about the nature of the discipline from the perspective of the reception of our work". Studies in Philosophy and Education 23, no. 5 (2004): 333-345. 
Depaepe, M. "Like a voice in the wilderness? Striving for a responsible handling of the educational heritage". In Exhibiting the Past: Public Histories of Education, edited by F. Herman, S. Braster \& M. del Mar del Pozo Andrés. Berlin: De Gruyter, 2022. In press.

Depaepe, M. "Qualities of Irrelevance? History of Education in the Training of Teachers". In Knowledge, Politics and the History of Education, edited by J. E. Larsen, 39-53. Münster: LIT-Verlag, 2012.

Depaepe, M. "Studying the history of education with textbooks: some reflections from our own research experiences". In Les manuels scolaires dans l'histoire de l'éducation: un enjeu patrimonial et scientifique, edited by M. Berré, F. Brasseur, C. Gobeaux \& R. Plisnier avec la collaboration de B. Bouchet, 111-121. Mons: CIPA, 2013.

Depaepe, M. "The Ten Commandments of Good Practices in History of Education Research". Zeitschrift für Pädagogische Historiographie 16, no. 1 (2010): 31-34.

Depaepe, M. "Über den Bildungswert von Schulmuseen”. In Bildungsmedien im wissenschaftlichen Diskurs, Hrsg. J. Benecke, A. Richter, H. Schulz-Gade, D. Balcke, M. Schmid. Bad Heilbrunn: Kilinkhardt, 2021. In press.

Depaepe, M. "Why even today educational historiography is not an unnecessary luxury. Focusing on four themes from forty-four years of research", Espacio, Tiempo y Educación 7, no. 1 (2020): 227-246.

Depaepe, M. et al. Order in Progress. Everyday Educational Practice in Primary Schools: Belgium, 1880-1970. Leuven: Leuven University Press, 2000.

Depaepe, M. "Sources in the Making of Histories of Education: proofs, arguments, and other reasonings from the historian's workplace". In Educational Research: Proofs, Arguments, and Other Reasonings, edited by P. Smeyers \& M. Depaepe, 23-39. Dordrecht: Springer, 2009.

Depaepe, M. and F. Simon. "It's All About Interpretation: Discourses at Work in Education Museums. The Case of Ypres". In Educational Research: Discourses of Change and Change of Discourse, edited by P. Smeyers \& M. Depaepe, 207-222. Cham: Springer International Publishing Switzerland, 2016.

Depaepe, M., F. Herman, M. Surmont, A. Van Gorp and F. Simon. "About Pedagogization: From the Perspective of the History of Education". In Educational Research: The Educationalization of Social Problems, edited by P. Smeyers \& M. Depaepe, 13-30. Dordrecht: Springer, 2008.

Depaepe, M., F. Simon and P. Verstraete. "Valorising the Cultural Heritage of the School Desk Through Historical Research". In Educational Research: Material Culture and Its Representation, edited by P. Smeyers and M. Depaepe, 13-30. Cham/Heidelberg/New York/Dordrecht \& London: Springer, 2014. 
Depaepe, M., F. Simon, M. Surmont and A. Van Gorp. “'Menschen in Welten’ Ordnungstrukturen des Pädagogischen auf dem Weg zwischen Haus und Schule”. Zeitschrift für Pädagogik 52, Beiheft (Juni 2007): 96-109.

Eeden, E. van and P. Nijssen. Jong in de jaren '70 .Utrecht/Antwerp:, Uitgeverij Kosmos, 1993.

Eyben, E. De ontstuimigen. Jeugd en ondeugd in het Oude Rome. Kapellen/Kampen: DNB-Uitgeverij Pelckmans/Uitgeverij Kok Agora, 1987.

Escolano, Agustín (Ed.). La cultura material de la escuela: en el centenario de la Junta para la ampliación de estudios, 1907-2007. Soria : CEINCE , 2007

Fendler, L. "Critical Powers of Historical Framing”. In Folds of Past, Present and Future: Reconfiguring Contemporary Histories of Education, edited by S. Van Ruyskensvelde, G. Thyssen, F., Herman, A., Van Gorp \& P. Verstraete, 59-80. Berlin: De Gruyter, 2021.

Feys, R., N. Gybels, P. Van Biervliet and S. Brasseur. "Vlaams onderwijs al lang mismeesterd. Onderwijskrant-memorandum 2019. Verzet/lippendienst leerkrachten temperde ontscholing/niveaudaling”. Onderwijskrant 189 (2019): 2-21.

Forgerson Hindley, A. and J. Olsen Edwards, "Early Childhood Racial Identity - The Potential Powerful Role for Museum Programming”. Journal of Museum Education 42, no. 1 (2017): 13-21.

Gautherin, J. Une discipline pour la république. La science de l'éducation en France (1882-1914). Berne: Peter Lang, 2002.

Gorp, A. Van. and M. Depaepe (Hrsg.). Auf der Suche nach der wahren Art von Textbüchern. Bad Heilbrunn: Verlag Julius Klinkhardt, 2009.

Halilović, J. “The War Childhood Museum: Creation and Principles”. Museum International 71, no. 1-2 (2019): 124-131.

Heese, Th. "Schulmuseen en Allemagne: histoire et situation actuelle des musées de l'école allemands". In Première rencontre francophone des musées de l'école. Actes Rouen 2016. Rouen: Le Musée national de l'éducation [Munaé], 2018.

Hentig, H. von. Ist Bildung nützlich?. In Metamorphosen der Bildung. Historie - Empirie - Theorie, edited by E. Keiner, K.-P. Horn, H. Kemnitz, U. Mietzner, U. Pilarczyk, J. Schuch and N. Welter, 395-412. Bad Heilbrunn: Klinkhardt, 2011.

Herman, F., A. Van Gorp, F. Simon and M. Depaepe. "The school desk: from concept to object”. History of Education 40, no. 1 (2011): 97-117.

Hernández Díaz, J.M. “Conversación con Marc Depaepe. Historiador de la educación, Universidad Católica de Lovaina (Bélgica)”, Historia de la educación 39 (2020): 437-459.

Hernández Díaz, J.M. “Museos pedagógicos y exposiciones educativas en España en los inicios del siglo XXI”. In I Foro Ibérico de Museísmo Pedagóxico. O 
museísmo pedagóxico en España e Portugal: Itinerarios, experiencias, e perspectivas. Actas, coordinado por V. Peña Saavedra, 117-171. Santiago de Compostela: Xunta de Galicia, 2003.

Herrmann, U. Historische Bildungsforschung und Sozialgeschichte der Bildung: Programme - Analysen - Ergebnisse. Weinheim: Deutscher Studien Verlag, 1990.

Jovanović, S. "Memories Taken Over. The Photo Archive of the Museum of Childhood". In Memories Taken Over. The Photo Archive of the Museum of Childhood, V. Perić. Belgrado: Museum of Applied Art, 2009.

Kestere, I. "The school theatre as a place of cultural learning: the case of Soviet Latvia (1960s-1980s)”. Paedagogica Historica 53 (2017): 318-341.

Kestere, I., Z. Rubene and I. Ozola. "Educational Sciences Between `Real’ Moscow and the 'Imaginary' West: The Case of Latvia (1989-1999). In Folds of Past, Present and Future: Reconfiguring Contemporary Histories of Education, edited by S. Van Ruyskensvelde, G. Thyssen, F., Herman, A., Van Gorp \& P. Verstraete, 67-282. Berlin: De Gruyter, 2021.

Kinchin, J. and A. O'Connor (Eds.). Century of the Child. Growing by Design, 1900-2000. New York: MOMA, 2012.

Koukos, E. and S. Folta, "Involving Cultural Institutions in the Prevention of Childhood Obesity: The Boston Children's Museum's GoKids Project". Journal of Nutrition Education and Behavior 42 (2010): 427-429.

Laets, C.y J. Strubbe. Jeugd in het Romeinse Rijk. Jonge jaren, wilde haren?. Leuven: Davidsfonds, 2008.

Lloyd, A. "Institutionalized stories': Childhood and national-socialism in contemporary German museum displays". Oxford German Studies 43, no. 1 (2014): 89-105.

Maas, F. “'Een bevrijdende, ontmoetende en soms helende dialoog'. Marc Depaepe over onderwijsmusea als laboratoria voor historisch-pedagogisch Onderzoek", Lessen. Periodiek van het Nationaal Onderwijsmuseum en de Vereniging van Vrienden 15, no. 2 (2020): 4-7.

McCulloch, G. The Struggle for the History of Education. London/New York: 2011.

Meda, J. "The "Sites of School Memory" in Italy between memory and oblivion: a first approach". History of Education \& Children's Literature 14, no. 1 (2019): 25-47.

Merry, M.S. and A. Schinkel. "What is an appropriate educational response to controversial historical monuments?". Journal of Philosophy of Education 40 (2021): 484-497.

Milligan M.J. and A. Brayfield. "Museums and childhood. Negotiating organizational lessons". Childhood 11, no. 3 (2004): 275-301. 
Moore, A.W. “Children We Have Lost: Diaries, Memoirs, and Museum Dispays of Childhood and Youth in Wartime Japan”. Cultural and Social History 17 (2020): 715-729.

Murken, "Das Kind in der Kunst als Spiegel der gesellschaftlichen Wandels". In Kinder des 20. Jahrhunderts. Malerei. Skulptur. Fotografie, edited by C. Murken, K. Weschenfelder and B. Schad, 8-28. Cologne: Wienand Verlag, 2000.

Nieuwenhuyse, K. Van; F. Simon \& M. Depaepe. “The Place of History in Teacher Training and in Education. A Plea for an Educational Future with a History, and Future Teachers with Historical Consciousness". Bildungsgeschichte. International Journal for the Historiography of Education 5, no.1 (2015): 57-69.

Nys, L. and J. Tollebeek. The city on the hill: a history of Leuven University, 19682005. Leuven: Leuven University Press, 2006.

Polenghi, S. and G. Bandini. "Interview with Marc Depaepe”, Espacio, Tiempo y Educación 3, no.1 (2016): 445-453.

Popkewitz, Thomas S. "The Study of Education. On Rethinking History with the Help of Marc Depaepe". In Folds of Past, Present and Future: Reconfiguring Contemporary Histories of Education, edited by S. Van Ruyskensvelde, G. Thyssen, F., Herman, A., Van Gorp \& P. Verstraete,39-58. Berlin: De Gruyter, 2021.

Possamai, Z. "Ferdinand Buisson and the emergence of pedagogical museums: clues of an international movement, nineteenth century". Paedagogica Historica 57, no. 4 (2021): 381-399.

Prior, N. Museums and Modenrity: Art Galleries and the Making of Modern Culture. Oxford/New York: Berg, 2002.

Rabazas Romero, Teresa, S. Ramos Zamora and J. Ruiz Berrio. "Incidencia para la Junta de Ampliación de Estudios en la modernización de la escuela española. La innovación del material escolar a través de los manuales de Pedagogía”. In La cultura material de la escuela. En el centenario de la Junta para la Ampliación de Estudios, 1907-2007, edited by A. Escolano Benito. Berlanga de Duero: Cience, 2007.

Reybrouck, D. Van. Revolusi. Indonesië en het ontstaan van de moderne wereld. Amsterdam: De Bezige Bij, 2020.

Rubio Mayoral, J.L. "Museos pedagógicos y experiencias educativas. Apuntes de futuro". In El patrimonio histórico-educativo y la enseñanza de la historia de la educación, 93-110. s.l.: Sociedad Española de la Historia de la Educación, 2009.

Ruiz Berrio, J. “El museísmo pedagógico en el mundo: pasado, presente y perspectivas de futuro". In I Foro Ibérico de Museísmo Pedagóxico. O museísmo pedagóxico en España e Portugal: Itinerarios, experiencias, e perspectivas. 
Actas, coordinado por V. Peña Saavedra, 55-72. Santiago de Compostela: Xunta de Galicia, 2003.

Schad, B. "Kindlichkeit als Metapher für Ursprünglichkeit. Die Kindbildnisse des Expressionismus". In Kinder des 20. Jahrhunderts. Malerei. Skulptur. Fotografie, edited by C. Murken, K. Weschenfelder and B. Schad, 29-41. Cologne: Wienand Verlag, 2000.

Simon F., "Afterword: inexhaustible cultural learning". Paedagogica Historica 53 (2017): 342-346.

Simon, F. "Education". In Historical Research in the Low Countries, edited by N.C.F. van Sas and E. Witte, 58-67. The Hague: Nederlands Historisch Genootschap, 1992.

Srobbe, J. 200 jaar dichters, denkers en durvers. Het Klein Seminarie van Roeselare. Biografie van een college. Tielt: Lannoo, 2006.

Steverlynck, C. with the cooperation of D. Dendooven \& L. Verschuren, Het grote geheim. Omgaan met lichamelijkheid en seksualiteit in opvoeding en on-

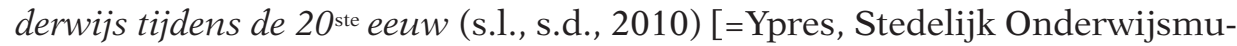
seum, 2010].

Straube-Heinze, K. and C. Heinze. Lesen Lernen im National-Sozialismus. Theoriekonzepte - Kindheitsbilden - Bildungspolitik. Bielefeld: Transcript Verlag, 2021.

Takševa, T. "Building a Culture of Peace and Collective Memory in Post-conflict Bosnia and Herzegovina: Sarajevo's Museum of War Childhood". Studies in Ethnicity and Nationalism 43, no. 1 (2018): 3-18.

Tenorth, H.E. Geschichte der Erziehung. Einführung in die Grundzüge ihrer neuzeitlichen Entwicklung. Weinheim/München: Juventa, 2000.

Vermeulen, J. Gezelle in context: taal, macht en identiteit .Brugge: Guido Gezellekring, 2021.

Vos, L. "Traditie als bron van vernieuwing. De katholieke studentactie in Vlaanderen, 1955-1975". Bijdragen tot de Eigentijdse Geschiedenis, no. 8 (2001): 133-179.

Vos, L. Bloei en ondergang van het AKVS. Geschiedenis van de Katholieke Vlaamse Studentenbeweging, 1914-1935. Leuven: Davidsfonds, 1982.

Welply, O. "A crisis in education? an Arendtian perspective on citizenship and belonging in France and England". British journal of sociology of education 40, no. 6 (2019): 759-775.

Zana Etambala, M. "A Virtual Visit to the Renovated Royal Museum for Central Africa. Two Major Challenges: Decolonization and Africanization". In Folds of Past, Present and Future: Reconfiguring Contemporary Histories of Education, edited by S. Van Ruyskensvelde, G. Thyssen, F., Herman, A., Van Gorp \& P. Verstraete, 147-174. Berlin: De Gruyter, 2021. 